Article

\title{
Iron Phosphide Precatalyst for Electrocatalytic Degradation of Rhodamine B Dye and Removal of Escherichia coli from Simulated Wastewater
}

\author{
Takwa Chouki $^{1}{ }^{1}$, Manel Machreki ${ }^{1}$, Jelena Topić ${ }^{2}$, Lorena Butinar ${ }^{3}$, Plamen Stefanov ${ }^{4}$, Erika Jez ${ }^{3}$, \\ Jack S. Summers ${ }^{5}$, Matjaz Valant ${ }^{1}(\mathbb{D})$, Aaron Fait ${ }^{6}(\mathbb{D})$ and Saim Emin ${ }^{1, *}$
}

Citation: Chouki, T.; Machreki, M.; Topić, J.; Butinar, L.; Stefanov, P.; Jez, E.; Summers, J.S.; Valant, M.; Fait, A.; Emin, S. Iron Phosphide Precatalyst for Electrocatalytic Degradation of Rhodamine B Dye and Removal of Escherichia coli from Simulated Wastewater. Catalysts 2022, 12, 269. https://doi.org/10.3390/ catal12030269

Academic Editors: Marc Cretin, Sophie Tingry and Zhenghua Tang

Received: 19 January 2022

Accepted: 21 February 2022

Published: 28 February 2022

Publisher's Note: MDPI stays neutral with regard to jurisdictional claims in published maps and institutional affiliations.

Copyright: (C) 2022 by the authors. Licensee MDPI, Basel, Switzerland. This article is an open access article distributed under the terms and conditions of the Creative Commons Attribution (CC BY) license (https:// creativecommons.org/licenses/by/ $4.0 /)$.
1 Materials Research Laboratory, University of Nova Gorica, 5270 Ajdovscina, Slovenia; takwa.chouki@student.ung.si (T.C.); manel.machreki@student.ung.si (M.M.); matjaz.valant@ung.si (M.V.)

2 Laboratory for Environmental and Life Sciences, University of Nova Gorica, 5000 Nova Gorica, Slovenia; jelena.topic@ung.si

3 Wine Research Centre, University of Nova Gorica, Glavni Trg 8, 5271 Vipava, Slovenia; lorena.butinar@ung.si (L.B.); erika.jez@ung.si (E.J.)

4 Institute of General and Inorganic Chemistry, Bulgarian Academy of Sciences, 1113 Sofia, Bulgaria; stefanov@svr.igic.bas.bg

5 Department of Chemistry and Physics, Western Carolina University, Cullowhee, NC 28723, USA; summers@email.wcu.edu

6 The Jacob Blaustein Institutes for Desert Research, Ben-Gurion University of the Negev, Midreshet Ben-Gurion 84990, Israel; aaron.fait@gmail.com

* Correspondence: saim.emin@ung.si; Tel.: +386-5-365-35-38

\begin{abstract}
Electrocatalysis using low-cost materials is a promising, economical strategy for remediation of water contaminated with organic chemicals and microorganisms. Here, we report the use of iron phosphide $\left(\mathrm{Fe}_{2} \mathrm{P}\right)$ precatalyst for electrocatalytic water oxidation; degradation of a representative aromatic hydrocarbon, the dye rhodamine B (RhB); and inactivation of Escherichia coli (E. coli) bacteria. It was found that during anodic oxidation, the $\mathrm{Fe}_{2} \mathrm{P}$ phase was converted to iron phosphate phase ( $\mathrm{Fe}_{2} \mathrm{P}$-iron phosphate). This is the first report that $\mathrm{Fe}_{2} \mathrm{P}$ precatalyst can efficiently catalyze electrooxidation of an organic molecule and inactivate microorganisms in aqueous media. Using a thin film of $\mathrm{Fe}_{2} \mathrm{P}$ precatalyst, we achieved $98 \% \mathrm{RhB}$ degradation efficiency and $100 \%$ E. coli inactivation under an applied bias of $2.0 \mathrm{~V}$ vs. reversible hydrogen electrode in the presence of in situ generated reactive chlorine species. Recycling test revealed that $\mathrm{Fe}_{2} \mathrm{P}$ precatalyst exhibits excellent activity and reproducibility during degradation of RhB. High-performance liquid chromatography with UV-Vis detection further confirmed the electrocatalytic (EC) degradation of the dye. Finally, in tests using Lepidium sativum L., EC-treated RhB solutions showed significantly diminished phytotoxicity when compared to untreated $\mathrm{RhB}$. These findings suggest that $\mathrm{Fe}_{2} \mathrm{P}$-iron phosphate electrocatalyst could be an effective water remediation agent.
\end{abstract}

Keywords: $\mathrm{Fe}_{2} \mathrm{P}$-iron phosphate; electrocatalysis; rhodamine B; Escherichia coli; reactive chlorine species

\section{Introduction}

Electrochemical oxidation has emerged as a promising means of eliminating contaminants from water [1]. The growing presence in wastewaters of organic pollutants such as pharmaceuticals, pesticides and dyes has become a major concern, as has the presence of heavy metals and pathogenic microorganisms. Removal of these substances is complex and energy-inefficient [2-7]. Anodic oxidation of organics at electrode surfaces is one set of methods for removing these contaminants $[8,9]$. Direct oxidation occurs by electron transfer between the substrate molecule and the electrode surface $[9,10]$, whereas indirect oxidation involves the generation of reactive oxygen species (ROS) or reactive chlorine species (RCS). 
ROS include hydroxyl radicals $(\bullet \mathrm{OH})$, hydrogen peroxide $\left(\mathrm{H}_{2} \mathrm{O}_{2}\right)$ and ozone $\left(\mathrm{O}_{3}\right)$. RCS include chlorine $\left(\mathrm{Cl}_{2}\right)$, hypochlorous acid $(\mathrm{HClO})$, chlorate $\left(\mathrm{ClO}^{-}\right)$and chlorine radicals $\left(\mathrm{Cl} \bullet\right.$ or $\mathrm{Cl}_{2}{ }^{\bullet-}$ ) [11-13]. RCS such as $\mathrm{Cl}_{2}$ and $\mathrm{HClO}$ have been shown to be effective in the degradation of alcohols [11], carboxylic acids [14], dyes [15], pharmaceuticals [16] and tannery effluents [17] and for inactivation of microorganisms [18]. During the process of RCS generation, oxidation of $\mathrm{Cl}^{-}$ions yields $\mathrm{Cl}_{2}$, which is stable in acidic medium $(\mathrm{pH}<3.3)$ or hydrolyzes to $\mathrm{HClO}(3.3<\mathrm{pH}<7.5)$ and $\mathrm{ClO}^{-}$ion $(\mathrm{pH}>7.5)$ [11]. The standard potential for the $\mathrm{Cl}_{2}$ evolution $\left(\mathrm{Cl}^{-} / \mathrm{Cl}_{2} 1.36 \mathrm{~V}\right.$ vs. normal hydrogen electrode (NHE)) is relatively low, making it an attractive option for efficient electrochemical wastewater treatment [19].

Electrochemical oxidation of organics usually allows the oxidation of pollutants to $\mathrm{H}_{2} \mathrm{O}$ and $\mathrm{CO}_{2}$. This approach is often used for remediation of organics, including dye molecules such as methylene blue [20], rhodamine B (RhB) [21] and methyl orange [20]. $\mathrm{RhB}$ removal from wastewater is particularly important due to its toxicity and carcinogenic effects [21].

The application of the electrocatalytic (EC) process for water disinfection has been investigated as well $[22,23]$. In water recycling, water disinfection constitutes the final crucial step, which represents the last barrier against harmful microorganisms [23,24]. Disinfection is necessary to remove harmful bacteria present in wastewater. These bacteria include Salmonella [25], Escherichia coli (E. coli) [26], Pseudomonas aeruginosa [18] and Enterococcus faecalis [27]. E. coli is the preferred indicator for fecal contamination in drinking water [28].

Materials such as platinum $(\mathrm{Pt})[26,29]$, iridium oxide $\left(\mathrm{IrO}_{2}\right)$ [30], titanium dioxide $\left(\mathrm{TiO}_{2}\right)$ [31,32], tin dioxide $\left(\mathrm{SnO}_{2}\right)[15,21,32]$, boron-doped diamond (BDD) $[21,33]$ and dimensionally stable anodes $\left(\mathrm{Ti} / \mathrm{TiO}_{2}-\mathrm{RuO}_{2}\right.$, $\left.\mathrm{Ti} / \mathrm{RuO}_{2}-\mathrm{IrO}_{2}\right)[15,34]$ have already been employed as electrocatalysts for $\mathrm{RhB}$ dye degradation and $E$. coli inactivation. Available evidence indicates that $\mathrm{Pt}$ and $\mathrm{IrO}_{2}$ are efficient catalysts for oxidation of $\mathrm{Cl}^{-}$ions that exhibit low-onset potential ( 1.42 V) for $\mathrm{Cl}_{2}$ evolution [35]. However, their widespread application is unfeasible since these materials are scarce and costly [36]. Other, less expensive materials, such as $\mathrm{TiO}_{2}, \mathrm{SnO}_{2}$ and $\mathrm{BDD}$, are inefficient electrocatalysts since they require high overpotential for $\mathrm{Cl}_{2}$ evolution [19].

Transition metal phosphides (TMPs) such as iron phosphide, copper phosphide, cobalt phosphide and nickel phosphide $[37,38]$ and transition metal phosphates (TMPHs) made of cobalt phosphate, nickel phosphate, manganese phosphate, iron phosphate, etc., have emerged as promising alternatives to the noble metal catalysts (e.g., Pt) for electrochemical water splitting $[38,39]$. TMPs and TMPHs show great promise as catalysts since they are made of abundant elements and offer high catalytic activity [38]. For example, $\mathrm{Fe}_{2} \mathrm{P}$ was demonstrated to deliver $10 \mathrm{~mA} \mathrm{~cm}^{-2}$ at an overpotential of $290 \mathrm{mV}$ vs. RHE to drive $\mathrm{O}_{2}$ evolution reaction (OER) in $1 \mathrm{M} \mathrm{KOH}$ [40]. On the other side, TMPH made of nickel-iron hydroxylphosphate (NiFe-OH-PO ${ }_{4}$ ) was shown to deliver a current density of $20 \mathrm{~mA} \mathrm{~cm}{ }^{-2}$ at an overpotential of $249 \mathrm{mV}$ for OER [41]. In addition to OER studies, TMP made of ternary NiCoFe phosphide was demonstrated as a suitable catalyst for oxidation of $\mathrm{Cl}^{-}$ ions to $\mathrm{Cl}_{2}$ gas [42]. The latter ability of TMPs can be used as an effective strategy in wastewater treatment where $\mathrm{Cl}^{-}$ions are present. Although TMPs are studied extensively, there are still unclear points associated with their stabilities observed during the water electrolysis experiments. The majority of the published articles on the use of TMPs in OER studies demonstrate the formation of a thin metal phosphate or metal oxide/hydroxide layer after the water electrolysis tests $[38,43,44]$. Often, the conclusion about the state of catalyst is drawn using techniques such as energy-dispersive X-ray spectroscopy or surface sensitive techniques such as $\mathrm{X}$-ray photoelectron spectroscopy. However, to properly address possible phase conversions, the use of $\mathrm{X}$-ray diffraction is also needed in addition to the above-mentioned techniques.

In the present study, $\mathrm{Fe}_{2} \mathrm{P}$ transformed into iron phosphate during electrocatalytic degradation of $\mathrm{RhB}$ dye and inactivation of E. coli bacteria. Since the phase is not well defined, it is abbreviated as $\mathrm{Fe}_{2} \mathrm{P}$-iron phosphate. To our knowledge, $\mathrm{Fe}_{2} \mathrm{P}$-iron phosphate 
electrocatalysts have never been applied for the degradation of organics and disinfection of water. First, we synthesized colloidal $\mathrm{Fe}_{2} \mathrm{P}$ nanoparticles (NPs) using a solvothermal approach, followed by spin-coating titanium (Ti) substrates with $\mathrm{Fe}_{2} \mathrm{P}$. To activate the $\mathrm{Fe}_{2} \mathrm{P}$ catalyst, a short heat treatment at $450{ }^{\circ} \mathrm{C}$ was carried out. The role of heat treatment is two-fold: first, to activate the catalyst by removal of organic capping molecules; second, to improve the adhesion of the catalyst onto the substrate [45]. The degradation of RhB was monitored using UV-Vis spectroscopy and high-performance liquid chromatography (HPLC) with spectroscopic monitoring. The inactivation of E. coli was monitored by plating bacteria suspension onto a medium after the treatment. Bacterial regrowth experiments and enumeration confirmed the rapid and complete inactivation of E. coli. Recycling test and linear sweep voltammetry revealed that $\mathrm{Fe}_{2} \mathrm{P}$-iron phosphate electrode exhibits excellent reproducibility. The catalysts were characterized using scanning electron microscopy (SEM), transmission electron microscopy (TEM), X-ray photoemission spectroscopy (XPS) and $\mathrm{X}$-ray diffraction $(\mathrm{XRD})$, along with other suitable electrochemical techniques.

\section{Results and Discussion}

\subsection{Characterization of $\mathrm{Fe}_{2} P$ Thin Films}

XRD diffractogram of the sample taken before heat treatment revealed that $\mathrm{Fe}_{2} \mathrm{P}$ is its sole constituent (Figure 1a). The intense diffraction peaks at 40.37, 44.30 and $52.91^{\circ}$ correspond to (111), (201) and (002) crystallographic planes of the hexagonal $\mathrm{Fe}_{2} \mathrm{P}(\overline{\mathrm{C}} 2 \mathrm{~m}$, PDF \# 1008826). The calculated crystal lattice parameters are in good agreement with the literature data for hexagonal $\mathrm{Fe}_{2} \mathrm{P}(a=b=5.851 \pm 0.0034 \AA$, and $c=3.507 \pm 0.0026 \AA)$ [46]. The crystallite size and the intrinsic strain calculated using the Williamson-Hall $(\mathrm{W}-\mathrm{H})$ method yielded an average size of $18 \pm 0.0010 \mathrm{~nm}$ and $4.5 \times 10^{-3} \pm 0.0007$ a.u., respectively (Text S1, Figure S1). The reliability of the refined fit was assessed by the weighted profile $\left(R_{\mathrm{wp}}\right)$ and Bragg $\left(R_{\mathrm{b}}\right)$ factor values that, at $R_{\mathrm{wp}}=4.23 \%$ and $R_{\mathrm{b}}=4.11 \%$, met the established criteria $\left(R_{\mathrm{wp}}<20 \%\right)$ for good refinement [47]. The XRD pattern of the $\mathrm{Fe}_{2} \mathrm{P}$ catalyst (Figure S2) after the heating procedure $\left(450^{\circ} \mathrm{C}\right)$ was almost identical to that recorded for the initially synthesized $\mathrm{Fe}_{2} \mathrm{P}$ NPs. This result confirms that the stoichiometry and crystal structure were unchanged by the procedure.

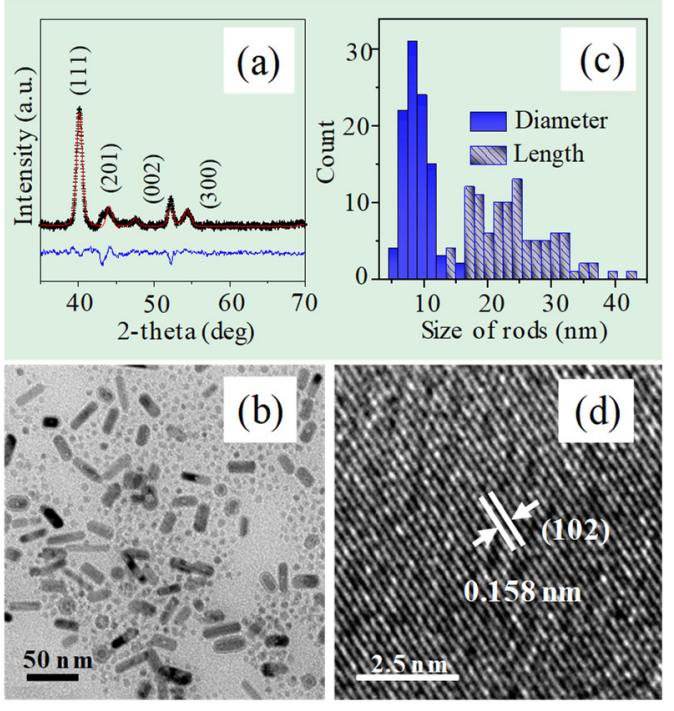

Figure 1. (a) XRD pattern of $\mathrm{Fe}_{2} \mathrm{P}$ with a Rietveld refinement fit. (b) TEM image of $\mathrm{Fe}_{2} \mathrm{P}$ NPs. (c) Size distribution plots of $\mathrm{Fe}_{2} \mathrm{P}$ NRs taken from (b). (d) HR-TEM image taken from an individual $\mathrm{Fe}_{2} \mathrm{P}$ NP.

TEM studies revealed that the obtained $\mathrm{Fe}_{2} \mathrm{P}$ sample contained two morphologies: nanospheres (NSs) and nanorods (NRs) (Figure $1 \mathrm{~b}$ ). The nanosphere $\mathrm{Fe}_{2} \mathrm{P}$ had a uniform diameter (about $5 \pm 0.1 \mathrm{~nm}$ on average, as shown in Figure S3), while $\mathrm{Fe}_{2} \mathrm{P}$ NRs varied in size (reaching $8.79 \pm 0.03 \mathrm{~nm}$ in diameter and $23 \pm 0.98 \mathrm{~nm}$ in length on average, as shown 
in Figure 1c). HR-TEM studies indicated that the lattice spacing of $0.158 \mathrm{~nm}$ corresponds to the (102) crystal plane of hexagonal $\mathrm{Fe}_{2} \mathrm{P}$ (Figure 1d).

We studied the morphology of the obtained $\mathrm{Fe}_{2} \mathrm{P}$ thin film using SEM. As seen in Figure $2 \mathrm{a}$, $\mathrm{b}$, the morphology of $\mathrm{Fe}_{2} \mathrm{P}$ thin film contains large aggregates and densely packed NPs. An SEM image taken at high magnification shows that the diameter of $\mathrm{Fe}_{2} \mathrm{P}$ particles is on the order of $200 \mathrm{~nm}$ (Figure 2c). The thickness of the resulting $\mathrm{Fe}_{2} \mathrm{P}$ film, as determined from the cross-section SEM image, is about $\sim 2 \mu \mathrm{m}$ (Figure $2 \mathrm{~d}$ ). EDS analysis combined with elemental maps for Fe and P confirmed that these agglomerates were made of iron phosphide and that the stoichiometric ratio of Fe:P elements is 2:1 (Figure 2e-i).
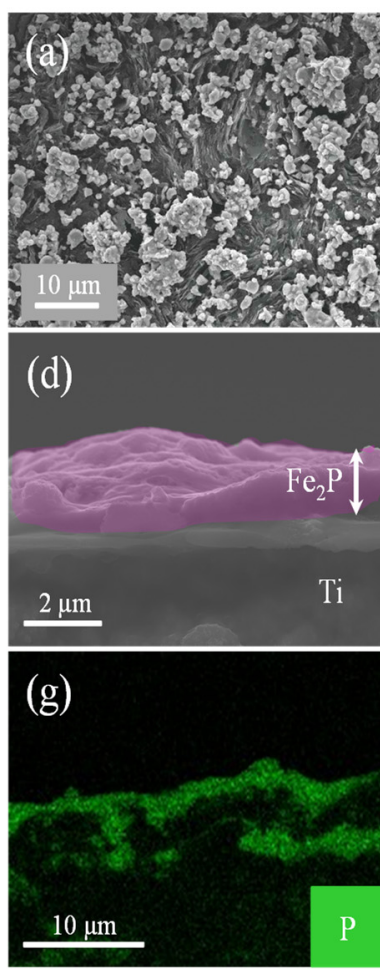
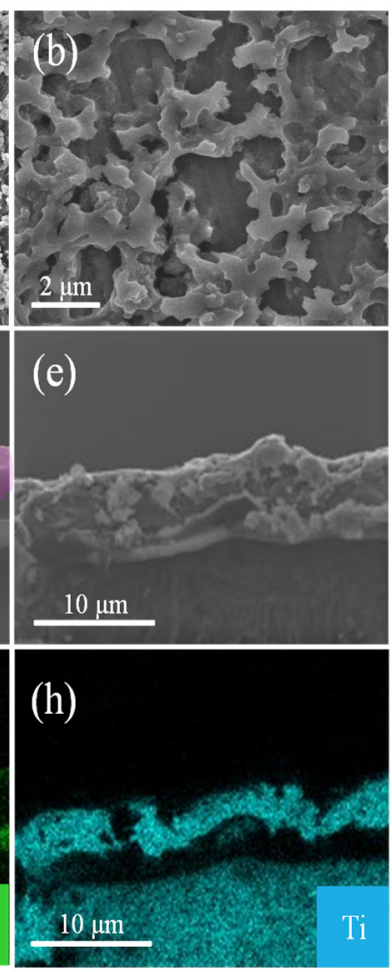
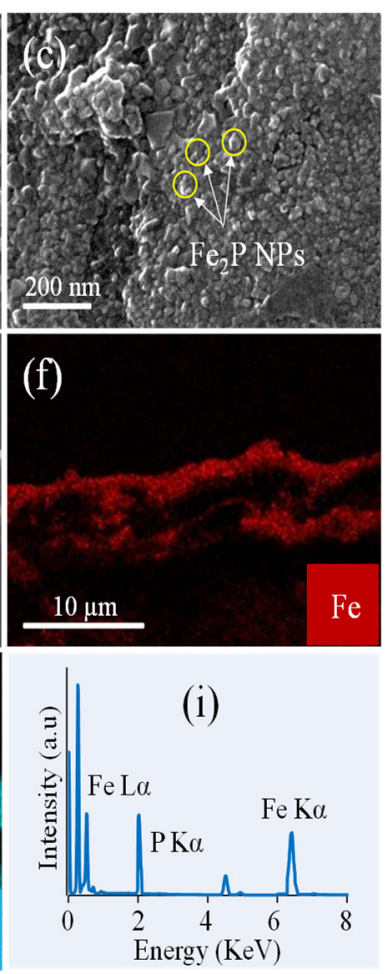

Figure 2. SEM images of $\mathrm{Fe}_{2} \mathrm{P}$ thin film at different magnifications in (a-c) top views and in (d) cross-sectional view. (f-h) Images with elemental maps are given for $\mathrm{Fe}, \mathrm{P}$ and $\mathrm{Ti}$, taken from the $\mathrm{Fe}_{2} \mathrm{P}$ sample shown in (e). (i) EDS spectrum recorded from the image in (e).

\subsection{Electrochemical Studies}

The catalytic activity of $\mathrm{Fe}_{2} \mathrm{P}$ films was studied using linear sweep voltammetry (LSV). Figure 3a shows liner sweep voltammograms of $\mathrm{Fe}_{2} \mathrm{P}$ film recorded in four electrolytes $(0.06 \mathrm{M})$, namely $\mathrm{NaCl}, \mathrm{NH}_{4} \mathrm{Cl}, \mathrm{Na}_{2} \mathrm{SO}_{4}$ and $\mathrm{NaOH}$. In each case, the recorded onset potential for Faradaic processes is close to $\sim 1.7 \mathrm{~V}$ vs. RHE. The current in $\mathrm{Na}_{2} \mathrm{SO}_{4}$ and $\mathrm{NaOH}$ electrolytes is lower due to the dominating $\mathrm{O}_{2}$ evolution reaction [48]. However, in the presence of $\mathrm{NaCl}$ and $\mathrm{NH}_{4} \mathrm{Cl}$ electrolytes, $\mathrm{O}_{2}$ evolution at the anode competes with oxidation of $\mathrm{Cl}^{-}$ions leading to $\mathrm{Cl}_{2}$. We also performed an LSV study with the $\mathrm{Fe}_{2} \mathrm{P}$ catalyst in $10^{-5} \mathrm{M}$ RhB solution $(0.06 \mathrm{M} \mathrm{NaCl}$ ) before the heat treatment experiment (Figure S4). We found that the current density is insufficiently low $\left(0.05 \mathrm{~mA} \mathrm{~cm}^{-2}\right.$ at $2 \mathrm{~V}$ vs. RHE) compared to that after the heating procedure at $450{ }^{\circ} \mathrm{C}$. The goal behind this heat treatment was to remove the organics that act as an insulating layer between the iron phosphide catalyst and the electrolyte [45]. The slopes of Tafel plots (plots of potential versus logarithm of current) are useful for interpreting polarization curves [45]. We found that the Tafel slopes obtained for $\mathrm{Fe}_{2} \mathrm{P}$ depended on the electrolyte. In solutions containing $0.06 \mathrm{M}$ electrolyte, the Tafel slopes were $144(\mathrm{NaCl}), 218\left(\mathrm{NH}_{4} \mathrm{Cl}\right), 227(\mathrm{NaOH})$ and $245\left(\mathrm{Na}_{2} \mathrm{SO}_{4}\right) \mathrm{mV} \mathrm{dec}^{-1}$ (Figure S5a). Since lower Tafel slope correlates with higher catalyst activity, this result is consistent with oxidation occurring fastest in $\mathrm{NaCl}$ solution (Text S2). Interfacial charge-transfer kinetics on 
$\mathrm{Fe}_{2} \mathrm{P}$ were analyzed using EIS measurements. This analysis showed that the charge transfer resistance $\left(R_{c t}\right)$ was low at high bias voltages, indicating fast charge-transfer kinetics during water oxidation reaction $\left(R_{\mathrm{ct}}<40 \mathrm{ohm} \mathrm{cm}^{2}\right)$ [49]. A Nyquist plot and a discussion of the relevant circuit and its analysis are presented in the supplemental section (Figure S5c). The electrochemically active surface area (ECSA) of the initial $\mathrm{Fe}_{2} \mathrm{P}$ film was determined from the CVs obtained in $1 \mathrm{M} \mathrm{KOH} \mathrm{(pH} \mathrm{14)} \mathrm{(Figure} \mathrm{S6)} \mathrm{[50].} \mathrm{The} \mathrm{calculated} \mathrm{ECSA} \mathrm{value} \mathrm{of}$ $0.6 \mathrm{~cm}^{2}$ exceeded the $0.3 \mathrm{~cm}^{2}$ geometric area (assuming a flat surface). The details of the calculation are described in Text S3.

(a)
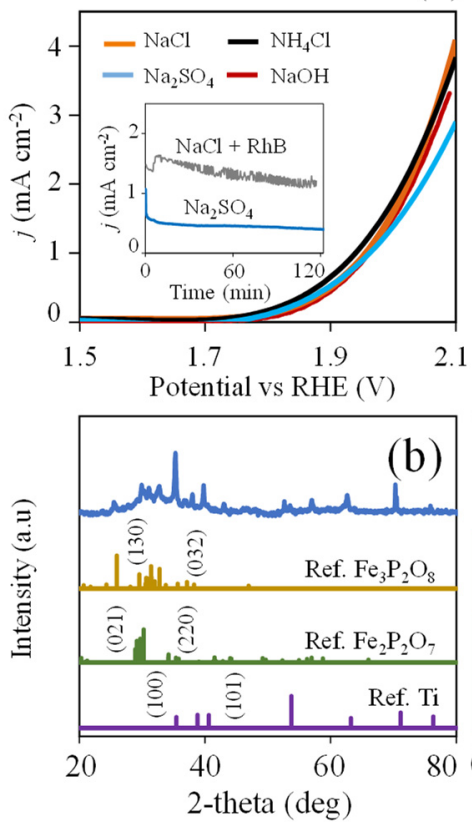

(c)

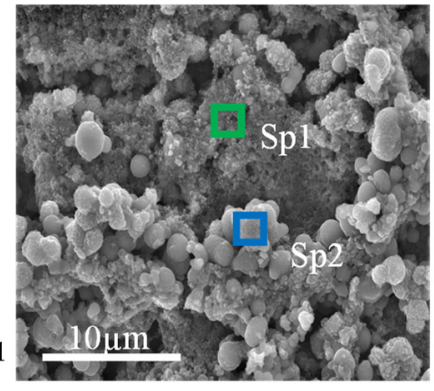

(d)

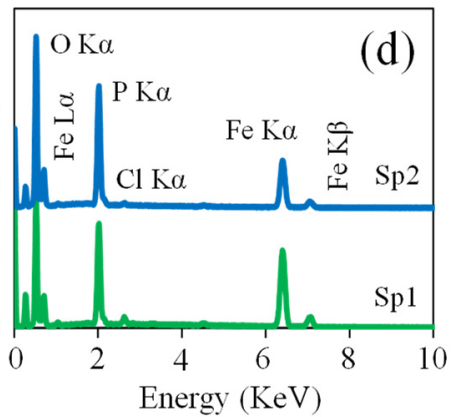

Figure 3. (a) LSV of $\mathrm{Fe}_{2} \mathrm{P}$ catalyst in $0.06 \mathrm{M} \mathrm{NaCl}, \mathrm{NH}_{4} \mathrm{Cl}, \mathrm{NaOH}$ and $\mathrm{Na}_{2} \mathrm{SO}_{4}$ at $\mathrm{pH}$ 5. The inset in (a) is the I-t plot obtained for different electrolytes with and without $1 \times 10^{-5} \mathrm{M}$ RhB at $2.0 \mathrm{~V}$ vs. RHE. (b) XRD pattern of $\mathrm{Fe}_{2} \mathrm{P}$ film after the electrolysis. References are given with labels. (c) SEM image of $\mathrm{Fe}_{2} \mathrm{P}$ after electolysis $\left(\mathrm{Cl}^{-}\right.$system). (d) EDS spectra recorded from the image in (c).

Chronoamperometric ( $I-t)$ experiments demonstrated that the $\mathrm{Fe}_{2} \mathrm{P}$ precatalyst satisfactorily retained the initial current level during the $2 \mathrm{~h}$ test time. These tests were conducted in $0.06 \mathrm{M} \mathrm{Na}_{2} \mathrm{SO}_{4}$ and in $0.06 \mathrm{M} \mathrm{NaCl}$ with $10^{-5} \mathrm{M} \mathrm{RhB}$ at an applied bias of $2.0 \mathrm{~V}$ vs. RHE (inset in Figure 3a). In $10^{-5} \mathrm{M}$ RhB solution, we observed a slight decrease in current level from 1.5 to $1.3 \mathrm{~mA} \mathrm{~cm}^{-2}$ during the initial $40 \mathrm{~min}$. However, the current level stabilized later. After the electrolysis, the film was studied using XRD (Figure 3b). Although there is an insignificant change in the current level during electrolysis, the XRD shows clearly the transformation of $\mathrm{Fe}_{2} \mathrm{P}$ phase into iron phosphate phase (mixture of $\mathrm{Fe}_{2} \mathrm{P}_{2} \mathrm{O}_{7}(\mathrm{PDF} \#$ 2300034) and $\mathrm{Fe}_{3} \mathrm{P}_{2} \mathrm{O}_{8}$ (PDF \# 2300033)). The obtained iron phosphate phase is composed of two phosphate phases, but we believe that a uniform single phase may occur after a sufficiently long electrolysis time. In addition to the XRD study, we also performed point EDS measurements from the image given in Figure $3 c$ after the EC degradation of RhB in $0.06 \mathrm{M} \mathrm{NaCl}$ (Figure 3d). EDS analysis confirmed that the atomic ratio of Fe:P is equal to 1.8:1 (Sp1). However, when we recorded spectrum 2 (Sp2), we noticed that the atomic ratio of Fe:P is equal to 1.4:1. In both spectra, we observed some additional peaks such as oxygen and $\mathrm{Cl}^{-}$ions. Images with elemental maps for $\mathrm{Fe}, \mathrm{P}, \mathrm{Cl}, \mathrm{O}$ and $\mathrm{C}$ taken from the $\mathrm{Fe}_{2} \mathrm{P}$ sample (after electrolysis) are provided in Figure S7. The low-intensity peak of $\mathrm{Cl}^{-}$ions indicates that these are adsorbed on the $\mathrm{Fe}_{2} \mathrm{P}$ surface in minor quantities $(0.6$ at. $\% \geq)$. The intense peak of oxygen confirms the formation of iron phosphate phase. From the obtained data, we concluded that a large amount of $\mathrm{Fe}_{2} \mathrm{P}$ film was converted to iron phosphate. The 
amount of metal phosphate obtained exceeds that reported in other systems where it was claimed that phase conversion occurs only on a few atomic surface layers [38,51].

\subsection{RhB Dye Degradation Studies}

The activity of the $\mathrm{Fe}_{2} \mathrm{P}$-iron phosphate thin film as an anode material for organic molecule degradation was studied by monitoring its effect on the absorbance spectra of a solution of RhB dye. As shown in Figure 4a, the $550 \mathrm{~nm}$ absorption peak of RhB was completely degraded to baseline in $40 \mathrm{~min}$ in $0.06 \mathrm{M} \mathrm{NH}_{4} \mathrm{Cl}(\mathrm{pH}$ 5). The degradation is much faster in $0.06 \mathrm{M} \mathrm{NaCl}$, being complete in under 2 min (a magnified region of $\mathrm{RhB}$ degradation in $0.06 \mathrm{M} \mathrm{NaCl}$ is shown in Figure S8). The slower degradation rate in $\mathrm{NH}_{4} \mathrm{Cl}$ electrolyte is attributed to ammonium cation $\left(\mathrm{NH}_{4}{ }^{+}\right)$oxidation which competes with $\mathrm{Cl}^{-}$ oxidation [52]. Pérez et al. (2012) showed that $\mathrm{NH}_{4}{ }^{+}$degrades to $\mathrm{N}_{2}$ and nitrate $\left(\mathrm{NO}_{3}{ }^{-}\right)$in reactions with oxidizing chlorine species [52] (Equations (1) and (2)):

$$
\begin{gathered}
2 / 3 \mathrm{NH}_{4}{ }^{+}+\mathrm{HClO} \rightarrow 1 / 3 \mathrm{~N}_{2}+\mathrm{H}_{2} \mathrm{O}+5 / 3 \mathrm{H}^{+}+\mathrm{Cl}^{-} \\
\mathrm{NH}_{4}{ }^{+}+4 \mathrm{HClO} \rightarrow \mathrm{NO}_{3}{ }^{-}+\mathrm{H}_{2} \mathrm{O}+6 \mathrm{H}^{+}+4 \mathrm{Cl}^{-}
\end{gathered}
$$

(a)
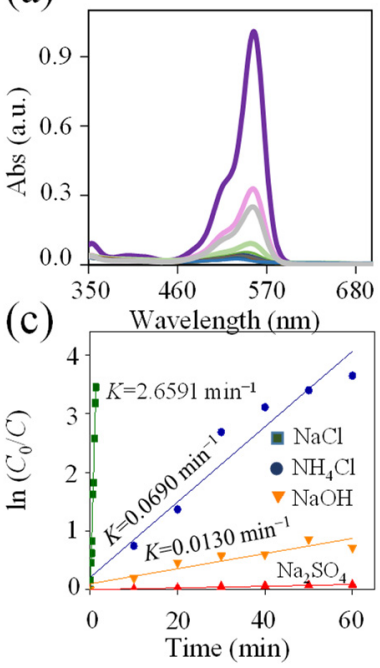

(b)

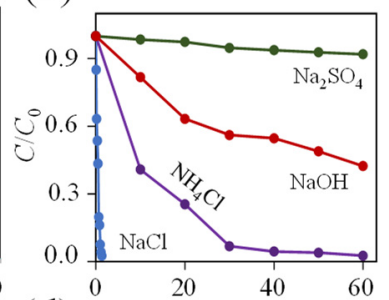

(d)

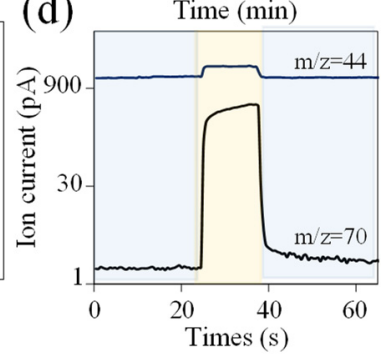

Figure 4. (a) Time-dependent absorption spectra of $\mathrm{RhB}$ in $0.06 \mathrm{M} \mathrm{NH}{ }_{4} \mathrm{Cl}$. (b) $\mathrm{C} / \mathrm{C}_{0}$ vs. time in different electrolytes at $2.0 \mathrm{~V}$ vs. RHE. (c) Pseudo-first-order degradation kinetics of RhB in different electrolytes at $2.0 \mathrm{~V}$ vs. RHE. (d) Ionic current vs. time detected using mass spectrometry.

When $\mathrm{Na}_{2} \mathrm{SO}_{4}$ and $\mathrm{NaOH}(\mathrm{pH} 5)$ were used as electrolytes, $\mathrm{RhB}$ dye degradation was negligible (Figure $4 \mathrm{~b}$ ). What degradation does occur is ascribed to the formation of $\mathrm{SO}_{4}{ }^{\bullet-}$ and $\bullet \mathrm{OH}$ species. However, it is well known that in an acidic environment $\mathrm{SO}_{4}^{\bullet-}$ radicals are less effective than $\bullet \mathrm{OH}$ radicals which favorably form in alkaline solutions [53]. In acidic media at $\mathrm{pH} 5$, the generation of $\bullet \mathrm{OH}$ is assumed to occur unfavorably. AlHamedi et al. (2009) demonstrated that $\bullet \mathrm{OH}$ reacts with $\mathrm{SO}_{4}{ }^{2-}$ ions, as shown in the following reaction:

$$
\mathrm{SO}_{4}{ }^{2-}+\bullet \mathrm{OH} \rightarrow \mathrm{SO}_{4}^{\bullet-}+\mathrm{OH}^{-}
$$

As a control experiment, we assessed the catalytic activity of pure Ti substrate in $0.06 \mathrm{M}$ $\mathrm{NaCl}$. In the absence of $\mathrm{Fe}_{2} \mathrm{P}$-iron phosphate, the bare Ti produced indistinct $\mathrm{RhB}$ dye degradation (Figure S8). We also investigated the kinetics of $\mathrm{Fe}_{2} \mathrm{P}$-iron phosphate catalyzed RhB oxidation. The RhB dye decomposition rate, presented in the form of degradation efficiency $(D)$, was calculated using the following equation: $D(\%)=\left(\left(C_{0}-C_{t}\right) / C_{0}\right) \times 100$, where $C_{0}$ is the initial concentration $(t=0 \mathrm{~min})$ and $C_{t}$ is the concentration at a defined reaction time point [54]. The highest $D$ value (equivalent to $98 \%$ ) was achieved in $0.06 \mathrm{M}$ 
$\mathrm{NaCl}$ within 1.3 min (Figure S9). The change in $\mathrm{RhB}$ dye concentration was assessed by a pseudo-first-order kinetic model: $\ln \left(C_{0} / C\right)=k_{1} t$, where $C$ and $C_{0}$ are the RhB dye concentrations at time $t$ and time zero, respectively, and $k_{1}$ is the pseudo-first-order rate constant calculated from the slope of the straight line (Text S4, Table S1) [55]. Our results are in good agreement with other published studies of electrochemical RhB degradation [15]. As shown in Figure 4c, the highest $k_{1}=2.6591 \mathrm{~min}^{-1}$ was obtained with $\mathrm{NaCl}$ electrolyte. This larger $k$ value indicates that $\mathrm{RhB}$ dye degraded about 1772 times faster than in $\mathrm{Na}_{2} \mathrm{SO}_{4}$ $\left(k_{1}=0.0015 \mathrm{~min}^{-1}\right)$ and 204 times faster than in $\mathrm{NaOH}$ electrolyte $\left(k_{1}=0.0130 \mathrm{~min}^{-1}\right)$. Here, the obtained $k_{1}$ constants in $\mathrm{Cl}^{-}$-containing electrolytes using $\mathrm{Fe}_{2} \mathrm{P}$-iron phosphate are higher than on other anode materials reported in earlier electrochemical studies. For example, using $\mathrm{Ti} / \mathrm{RuO}_{2}-\mathrm{IrO}_{2}$ catalyst during $\mathrm{RhB}$ dye degradation under $\mathrm{EC}$ condition yielded $k_{1}=0.079 \mathrm{~min}^{-1}$ [15].

Coumarin was used as a probe molecule to determine whether $\bullet \mathrm{OH}$ radicals participate in RhB degradation in chloride solutions (Text S5). This molecule reacts with $\bullet \mathrm{OH}$ radicals to form a highly fluorescent product called 7-HC which has a peak at $\sim 456 \mathrm{~nm}$ [56]. The absence of a $7-\mathrm{HC}$ emission peak suggests that $\bullet \mathrm{OH}$ radicals are suppressed in $\mathrm{NaCl}$ electrolyte (Figure S10) [11]. Results of the experiments described above suggest that EC degradation of RhB occurs via an indirect oxidation mechanism in which RCS, but not ROS, play a crucial role [57]. To further test this hypothesis, we measured the evolution of in situ generated $\mathrm{Cl}_{2}$ using the DPD colorimetric method [58]. In the presence of $\mathrm{Cl}_{2}$, DPD is oxidized to a radical cation (DPD $\bullet^{+}$) with an absorption peak at $515 \mathrm{~nm}$ [59]. In these experiments, we observed the growth of the $515 \mathrm{~nm}$ peak, further supporting the proposal that RCS participate in RhB degradation (Figure S11). The results are consistent with the EC-chlorine system where $\mathrm{HClO}$ plays an essential role during the degradation of $\mathrm{RhB}[30,60]$. In a similar way, Baddouh et al. (2018) have previously demonstrated the electrooxidation of $\mathrm{Cl}^{-}$to $\mathrm{HClO}$ at $\mathrm{Ti} / \mathrm{RuO}_{2}-\mathrm{IrO}_{2}$ anode. At $\mathrm{pH} 5, \mathrm{HClO}$ is expected to be the dominant form of RCS [58].

To further confirm RCS participation in the electrochemical degradation of RhB, we monitored the evolution of $\mathrm{Cl}_{2}$ using mass spectrometry (MS) (Figure 4d). The sudden rise in ionic current at $25 \mathrm{~s}$ indicates the presence of fragment ions with the mass-to-charge ratio $(\mathrm{m} / z)$ for $\mathrm{Cl}_{2}$ and $\mathrm{CO}_{2}$ equal to 70 and 44 , respectively. Here, $\mathrm{CO}_{2}$ is produced from $\mathrm{RhB}$ degradation during the electrocatalytic oxidation process. On the counter electrode, the $\mathrm{H}_{2}$ gas is evolved (Figure S12).

Further support for our hypothesis that $\mathrm{HClO}$ participates in $\mathrm{RhB}$ degradation comes from chemical oxidation studies with $\mathrm{NaOCl}$ (Figure 5). We found that complete dye decolorization was achieved using $\sim 0.4 \mathrm{mM} \mathrm{NaOCl}$. This result further supports the hypothesis that RhB decolorization in EC mode is mainly conducted by the generated $\mathrm{HClO}$ species (the RhB degradation mechanism is discussed in detail in Text S6). Under potentiostatic conditions (at $2.0 \mathrm{~V}$ vs. RHE) during the 4 min reaction process in $0.06 \mathrm{M}$ $\mathrm{NaCl}$, the amount of measured $\mathrm{HClO}$ is estimated as $2.5 \mathrm{mg} \mathrm{L}^{-1}$ (Figure S11), which corresponds to a current to $\mathrm{HClO}$ conversion efficiency of $73.7 \%$ (Text S7).

As indicated in studies of EC-mediated azo dye degradation, applied potential can significantly influence the degradation efficiency [5]. Herein, we studied RhB degradation in $0.06 \mathrm{M} \mathrm{NaCl}$ at three bias potentials $(1.8,1.9$ and $2.0 \mathrm{~V}$ vs. RHE, Figure $6 \mathrm{a})$. In this experiment, $>97 \%$ degradation was observed in $1.3 \mathrm{~min}$ at $2.0 \mathrm{~V}$ and in $20 \mathrm{~min}$ at $1.9 \mathrm{~V}$ (voltage vs. RHE). In contrast, at an applied potential of $1.8 \mathrm{~V}, 56 \%$ efficiency was achieved in $20 \mathrm{~min}$ (Figure S9b). Thus, higher potentials give rise to fast oxidation of $\mathrm{Cl}^{-}$to RCS, leading to rapid dye degradation.

We evaluated the stability of the $\mathrm{Fe}_{2} \mathrm{P}$-iron phosphate film against corrosion under conditions of the EC reaction by performing an experiment where a single $\mathrm{Fe}_{2} \mathrm{P}$-iron phosphate film was used to degrade multiple samples of RhB. Figure $6 \mathrm{~b}$ shows the result of this recycling test for RhB degradation at $1.9 \mathrm{~V}$ vs. RHE bias potential in $0.06 \mathrm{M} \mathrm{NaCl}$. The data in Figure $6 \mathrm{~b}$ reveal over $97 \%$ RhB degradation efficiency for each of the four runs, 
confirming the stability of $\mathrm{Fe}_{2} \mathrm{P}$-iron phosphate thin film against corrosion and the potential for its reuse in EC studies.

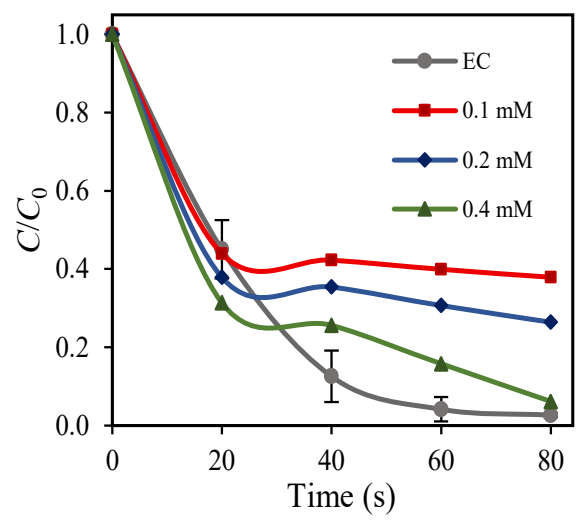

Figure 5. Comparison of $\mathrm{RhB}$ degradation in the $\mathrm{EC}$ system under $0.06 \mathrm{M} \mathrm{NaCl}$ vs. chemical oxidation at different $\mathrm{NaOCl}$ concentrations.
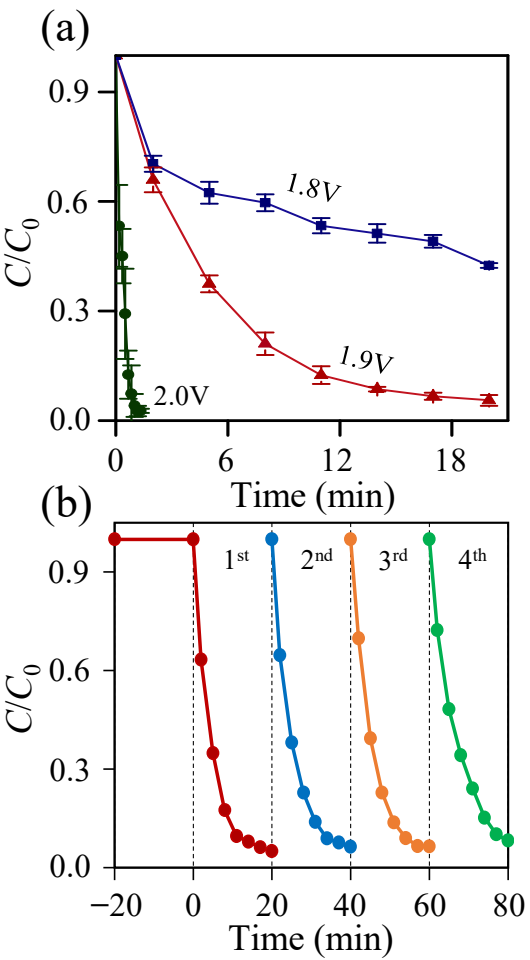

Figure 6. (a) $C / C_{0}$ vs. time during EC degradation of $\mathrm{RhB}$ over $\mathrm{Fe}_{2} \mathrm{P}$-iron phosphate at different applied potentials in $0.06 \mathrm{M} \mathrm{NaCl}$. (b) Recycling test for $\mathrm{EC}$ degradation of $\mathrm{RhB}$ over $\mathrm{Fe}_{2} \mathrm{P}$-iron phosphate in $0.06 \mathrm{M} \mathrm{NaCl}$ at $1.9 \mathrm{~V}$ vs. RHE.

The stability of the $\mathrm{Fe}_{2} \mathrm{P}$-iron phosphate films was further validated by LSV characterization of films before and after the reusability tests. We characterized the electrochemical activity of the film by LSV and the surface morphology by SEM (Figure S13). The LSV measurements revealed a slight increase in current after the stability test. The SEM measurements showed that film morphology was unaltered by the EC process. Both these results confirm the adequacy and compatibility of this electrode in EC wastewater treatment.

The composition and chemical state of $\mathrm{Fe}_{2} \mathrm{P}$ thin film were characterized by XPS. As with the characterization studies described above, we measured XPS data before and after exposing the $\mathrm{Fe}_{2} \mathrm{P}$ film to $\mathrm{EC}$ conditions. The spectrum of the $\mathrm{Fe}_{2} \mathrm{P}$ electrode before $\mathrm{RhB}$ degradation is shown in Figure 7a. Selected regions of the XPS spectra recorded before and 
after RhB degradation are shown in Figure $7 \mathrm{~b}-\mathrm{d}$. The photoelectron Fe $2 \mathrm{p}$ peaks exhibit a doublet at $711.0 \mathrm{eV}\left(\mathrm{Fe} 2 \mathrm{p}_{3 / 2}\right)$ and $724.0 \mathrm{eV}\left(\mathrm{Fe} \mathrm{2} \mathrm{p}_{1 / 2}\right)$ due to spin-orbit splitting. A less intense peak is also observed at $713.5 \mathrm{eV}$. These peaks can be attributed to the formation of iron(III) phosphate on the $\mathrm{Fe}_{2} \mathrm{P}$ surface [61]. The $\mathrm{P} 2 \mathrm{p}$ spectrum displays two peaks with 133.0 and $134.0 \mathrm{eV}$ binding energies, which are attributed to $P 2 p_{3 / 2}$ and $P 2 p_{1 / 2}$ levels of $P$ in the $\mathrm{Fe}_{2} \mathrm{P}$ [61]. The peak at $133 \mathrm{eV}$ can be assigned to $\mathrm{P}-\mathrm{C}$ binding [62]. Because the surface oxidation of the $\mathrm{Fe}_{2} \mathrm{P}$ particles is unavoidable, the peak at $134.0 \mathrm{eV}$ has been observed for phosphorus in a high oxidation state and refers to surface-oxidized P species [61]. These findings suggest that these species can also be assigned to the formation of a thin iron phosphate layer. To gain a better understanding of $\mathrm{Fe}_{2} \mathrm{P}$ catalyst stability, we also recorded XPS spectra after the EC degradation of RhB dye (Figure 7). The intensities of the XPS core-level spectra of Fe $2 p$ and P 2p greatly decreased after the test. Moreover, an intense peak formed at $201.5 \mathrm{eV}$ and was attributed to the $\mathrm{Cl} 2 \mathrm{p}$ core-level emission (Figure $7 \mathrm{~d}$ ). These results confirm that, during EC degradation, $\mathrm{Cl}^{-}$ions are strongly adsorbed on the $\mathrm{Fe}_{2} \mathrm{P}$ surface. Moreover, the large amount of chloride ions adsorbed on the surface attenuates the signal from $\mathrm{Fe}_{2} \mathrm{P}$, thus markedly decreasing the intensity of the $\mathrm{Fe} 2 \mathrm{p}$ and $\mathrm{P}$ $2 p$ peaks. These results are in good agreement with the EDS analysis.

(a)

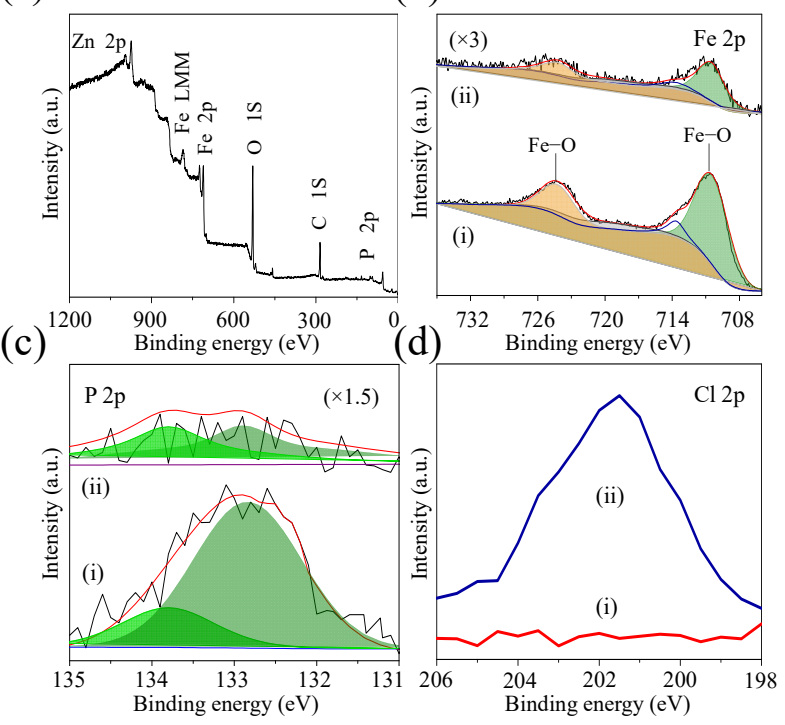

Figure 7. (a) XPS survey spectrum of $\mathrm{Fe}_{2}$ P. (b-d) XPS core-level spectra of Fe 2p, P 2p and Cl 2p recorded (i) before and (ii) after the test.

We employed HPLC to monitor RhB dye degradation. The reference sample of RhB dye produced an apparent peak at 15.0 min elution time (Figure 8). We monitored the disappearance of the $\mathrm{RhB}$ absorbance peak $(\lambda=550 \mathrm{~nm})$ in $\mathrm{NaCl}, \mathrm{NH}_{4} \mathrm{Cl}$ and $\mathrm{Na}_{2} \mathrm{SO}_{4}$. As shown in Figure S14, complete degradation was accomplished within 2 min in $0.06 \mathrm{M} \mathrm{NaCl}$ and $60 \mathrm{~min}$ in $0.06 \mathrm{M} \mathrm{NH}_{4} \mathrm{Cl}$ while degradation in $0.06 \mathrm{M} \mathrm{Na}_{2} \mathrm{SO}_{4}$ remained incomplete after $180 \mathrm{~min}$. Monitoring degradation at multiple detection wavelengths failed to show the appearance of additional peaks in the HPLC chromatograms. This indicates that no degradation by-products with strong absorption in the UV-Vis are formed. From this, we conclude that complete degradation occurs in $\mathrm{Cl}^{-}$-containing electrolytes (Figure 8). The use of HPLC was also motivated by the fact it overcomes the interference of $\mathrm{Cl}^{-}$ions seen as a bottleneck in other methods such as the total organic carbon and the chemical oxygen demand. 

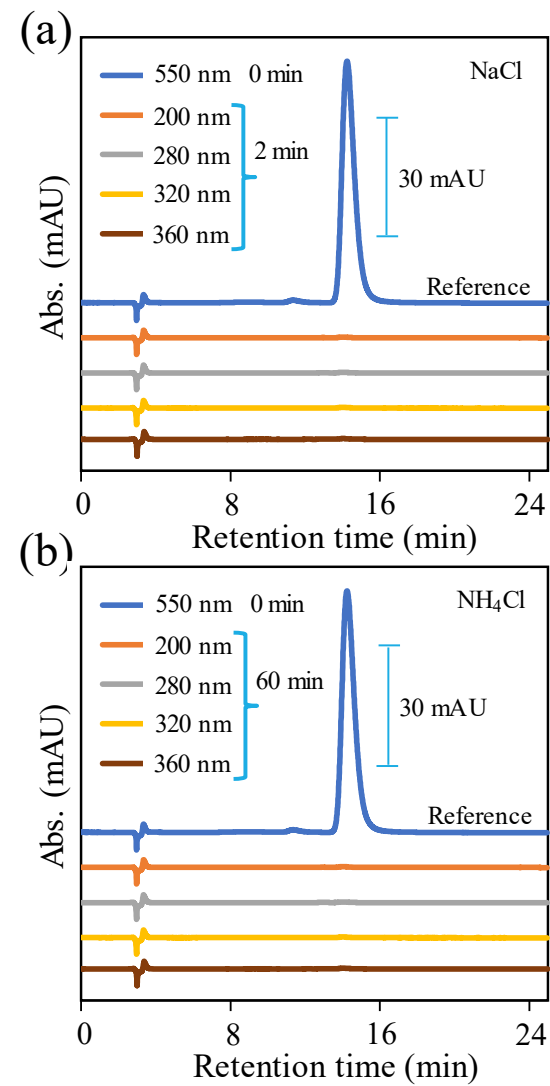

Figure 8. HPLC chromatograms of RhB measured after the $\mathrm{EC}$ treatment in (a) $0.06 \mathrm{M} \mathrm{NaCl}$ after 2 min test with different $\lambda_{\text {det }}$ and (b) $0.06 \mathrm{M} \mathrm{NH}_{4} \mathrm{Cl}$ measured after 60 min at different $\lambda_{\text {det }}$, using $1 \times 10^{-5} \mathrm{M}$ RhB aqueous solution as the reference.

In earlier studies related to EC wastewater treatment, chlorate or perchlorate ions were identified as by-products [63]. We note that these by-products were observed when the applied current densities were in the $5-30 \mathrm{~mA} \mathrm{~cm}^{-2}$ range [64]. Consequently, we believe that chlorate formation is less likely under the conditions adopted in our study since the current densities do not exceed $2 \mathrm{~mA} \mathrm{~cm}^{-2}$. Further, the detection at shorter wavelengths $(200 \mathrm{~nm})$ in HPLC demonstrates that intermediates with lower molecular weight (phthalic acid, benzoic acid, $\alpha$-hydroxyglutaric acid, etc.) which might form during $\mathrm{RhB}$ degradation [65] are absent from our reaction medium after the EC treatment process.

\subsection{Phytotoxicity Test of RhB and Electrochemical Inactivation of E. coli Bacteria}

\subsubsection{Phytotoxicity Test of RhB}

To assess the quality of EC-treated RhB water solutions, phytotoxicity test was performed using L. sativum whereby seed germination index and root growth of L. sativum were used to evaluate the phytotoxic effect of $\mathrm{RhB}$ in $0.06 \mathrm{M} \mathrm{NaCl}$ at pH 5 (Figure S15). Before electrochemical treatment, the germination index for L. sativum in RhB solution, $0.06 \mathrm{M} \mathrm{NaCl}$, pH 5 was $75.9 \%$. After electrochemical treatment of this solution, the germination index rose to $84 \%$. Similarly, the average root length increased from 17.7 to $18.9 \mathrm{~mm}$ after treatment (Figure 9a). These results show electrochemically treated solutions have little to no phytotoxicity [66] (further details about our phytotoxicity study are provided in Text S8). 
(a)

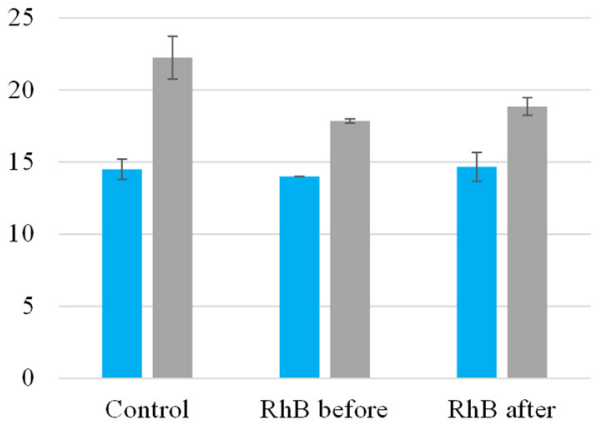

(b)

m Seed germination (number) $⿴$ Average root lenght (mm)

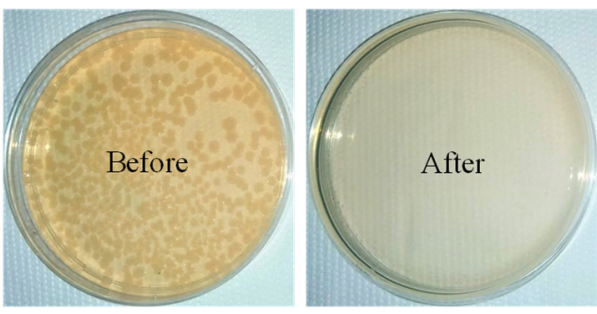

Figure 9. (a) Seed germination test for toxicity analysis of RhB solutions. (b) Growth of E. coli on agar plate before the EC treatment and after $40 \mathrm{~min}$ of exposure of E. coli to EC treatment.

\subsubsection{Electrochemical Inactivation of E. coli Bacteria}

Inactivation of E. coli using the $\mathrm{Fe}_{2} \mathrm{P}$-iron phosphate thin film electrode was investigated in $\mathrm{NaCl}$ electrolyte. The catalytic activity of $\mathrm{Fe}_{2} \mathrm{P}$-iron phosphate films was determined using the LSV method. Figure S16a shows LSV characteristics of $\mathrm{Fe}_{2} \mathrm{P}$-iron phosphate film recorded in $0.06 \mathrm{M} \mathrm{NaCl}(\mathrm{pH} 5)$, with the initial $E$. coli concentration, determined with plating, being $1.1 \times 10^{8} \mathrm{CFU} / \mathrm{mL}$. The recorded onset potential is close to $1.7 \mathrm{~V}$ vs. RHE. Figure $\mathrm{S} 16 \mathrm{~b}$ shows the chronoamperometric experiment of $\mathrm{Fe}_{2} \mathrm{P}$-iron phosphate catalyst conducted in $0.06 \mathrm{M} \mathrm{NaCl}$ with $1.1 \times 10^{8} \mathrm{CFU} / \mathrm{mL}$ of E. coli at an applied bias of $2.0 \mathrm{~V}$ vs. RHE. We observed a decrease in current density during the first $90 \mathrm{~min}$, starting from $0.9 \mathrm{~mA} \mathrm{~cm}^{-2}$. However, the current density later stabilized and reached a plateau at $0.46 \mathrm{~mA} \mathrm{~cm}^{-2}$. The activity of the $\mathrm{Fe}_{2} \mathrm{P}$-iron phosphate electrode was further validated by LSV after the stability test (inset in Figure S16a). The LSV measurement revealed a slight decrease in current after the 120 min stability test, which confirms the suitability of this electrode in EC water disinfection. After $40 \mathrm{~min}$ of EC exposure at $0.9 \mathrm{~mA} \mathrm{~cm}{ }^{-2}$, no viable bacteria were detected, indicating $100 \%$ disinfecting efficiency in $\mathrm{NaCl}$ electrolyte (Figure 9b). However, in comparison to the initial E. coli concentration, we observed a 26.7\% decline in the control bacterial solution after $160 \mathrm{~min}$ incubation in $0.06 \mathrm{M} \mathrm{NaCl}(\mathrm{pH} 5)$ without EC treatment.

One of the major concerns of electrodisinfection involving active chlorine is the formation of chlorination by-products $\left(\mathrm{ClO}_{2}{ }^{-}\right.$and $\left.\mathrm{ClO}_{3}{ }^{-}\right)$. However, it is known that chlorate formation occurs at higher current densities and is less likely to evolve under the conditions $\left(0.9 \mathrm{~mA} \mathrm{~cm}^{-2}\right)$ adopted in our study [64].

All these results indicate that the EC treatment with $\mathrm{Fe}_{2} \mathrm{P}$-iron phosphate electrodes is a promising alternative procedure compared with other known materials considering the high-efficiency processes for dye degradation (Table S2) and water disinfection (Table S3).

\section{Materials and Methods}

\subsection{Chemicals}

The following chemicals were used in this study: oleylamine (70\%, OLA), iron pentacarbonyl $(99.9 \%, \mathrm{Fe}(\mathrm{CO}) 5)$, acetone $(95 \%)$, ethanol $(98 \%)$ and potassium hydroxide $(97 \%$, $\mathrm{KOH})$, obtained from Sigma-Aldrich; triphenylphosphine (99\%, TPP), RhB ( $\geq 95 \%)$, squa- 
lene $(98 \%, \mathrm{SQ})$, chloroform $\left(99.5 \%, \mathrm{CHCl}_{3}\right)$, sodium sulfate $\left(99 \%, \mathrm{Na}_{2} \mathrm{SO}_{4}\right)$, sodium chloride $(99 \%, \mathrm{NaCl})$, coumarin and sodium hypochlorite $(\mathrm{NaOCl})$, purchased from Alfa Aesar; ammonium chloride $\left(\geq 99 \%, \mathrm{NH}_{4} \mathrm{Cl}\right)$ and 7-hydroxycoumarin (7-HC), acquired from Acros Organics; and a titanium block (99.9\%) obtained from Baoji Quanjin Industry \& Trade Co., Ltd. (Baoji, China).

\subsection{Preparation of $\mathrm{Fe}_{2} \mathrm{P}$ Thin Films}

$\mathrm{Fe}_{2} \mathrm{P}$ was synthesized using TPP precursor adopting the method described by Chouki et al. (2020) [45]. The synthesis procedure and the experimental measurements are described in detail in Text S9 and S10 in Supporting Information (SI).

\subsection{E. coli Preparation and Evaluation of Removal Efficiency}

One colony from a 2-day-old culture of E. coli DSM 489, grown on tryptic soy agar (Fluka), was inoculated into $50 \mathrm{~mL}$ liquid tryptone medium (Fluka) in $250 \mathrm{~mL}$ Erlenmeyer flask and incubated for $16 \mathrm{~h}$ at $37^{\circ} \mathrm{C}(150 \mathrm{rpm})$. The culture was centrifuged at $4000 \mathrm{rpm}$ for $10 \mathrm{~min}$, and bacterial cells were washed with filter-sterilized $0.06 \mathrm{M} \mathrm{NaCl}$ (pH 5) solution. Bacterial solution was adjusted to O.D. $(600 \mathrm{~nm}) 0.15$ and used for electrochemical removal of $1.1 \times 10^{8} \mathrm{CFU} / \mathrm{mL}$. coli bacteria in $0.06 \mathrm{M} \mathrm{NaCl}$ at an applied bias of $2.0 \mathrm{~V}$ vs. RHE.

To evaluate E. coli removal efficiency, samples were withdrawn at four different time points with 40 min increment during the EC experiment. The control bacterial suspension without any treatment was also plated at the beginning and at the end of the experiment. Serial dilutions (10-fold) of samples were spread onto plates with the tryptic soy agar (Fluka). Plates were counted after $24 \mathrm{~h}$ incubation at $37^{\circ} \mathrm{C}$ and bacterial counts were expressed as CFU/mL.

\subsection{Phytotoxicity Test Using Lepidium sativum L.}

Lepidium satioum L. (L. sativum) was used to assess the acute toxicity of RhB before and after treatment in $0.06 \mathrm{M} \mathrm{NaCl}$ at $\mathrm{pH}$. The test is described in the SI.

\section{Conclusions}

In this work, we report for the first time the transformation of $\mathrm{Fe}_{2} \mathrm{P}$ into iron phosphate during EC degradation of RhB dye (98\%) and inactivation of E. coli bacteria (100\%). We demonstrated that, under the experimental conditions, $\mathrm{Cl}^{-}$ions are oxidized to $\mathrm{HClO}$, which plays an essential role in the water treatment process. The recycling test (degradation test) of $\mathrm{RhB}$ dye over $\mathrm{Fe}_{2} \mathrm{P}$-iron phosphate film at $1.9 \mathrm{~V}$ vs. RHE revealed excellent reproducibility. Phytotoxicity tests revealed that EC treatment of RhB solutions decreased the inhibition of L. sativum germination, which serves as an indicator for reduced toxicity. Hence, this work demonstrates the tremendous potential of $\mathrm{Fe}_{2} \mathrm{P}$-iron phosphate as an efficient electrocatalyst in water cleaning studies. We propose that EC degradation of organics and inactivation of pathogenic bacteria could be also extended to other TMPHs.

Supplementary Materials: The following supporting information can be downloaded at: https: / / www.mdpi.com/article/10.3390/catal12030269/s1. Text S1: Rietveld refinement analysis and Williamson-Hall method. Figure S1: Williamson-Hall plot. Figure S2: XRD pattern of $\mathrm{Fe}_{2} \mathrm{P}$ after heat treatment. Figure S3: Size distribution of $\mathrm{Fe}_{2} \mathrm{P}$ NSs. Figure S4: LSV characteristic of $\mathrm{Fe}_{2} \mathrm{P}$ particles recorded in $10^{-5} \mathrm{M} \mathrm{RhB}+0.06 \mathrm{M} \mathrm{NaCl}$ conducted before heat treatment. Text S2: Tafel plots and EIS. Figure S5: (a) Tafel plots of different electrolytes; (b) Nyquist plot of $\mathrm{Fe}_{2} \mathrm{P}$ thin film in $0.06 \mathrm{M} \mathrm{Na}_{2} \mathrm{SO}_{4}$; (c) Charge transfer resistance vs. applied voltages; (d) A circuit element used to fit the data. Text S3: Calculation of electrocatalytic active surface area. Figure S6: $\mathrm{CVs}$ of $\mathrm{Fe}_{2} \mathrm{P}$ at different scan rates in $1 \mathrm{M} \mathrm{KOH}$; (b) Current vs. scan rate taken from (a). Figure S7: Images with elemental maps are given for $\mathrm{Fe}, \mathrm{P}, \mathrm{Cl}, \mathrm{O}$ and $\mathrm{C}$ taken from the $\mathrm{Fe}_{2} \mathrm{P}$ sample (after electrolysis). Figure S8: Time profiles of $\mathrm{RhB}$ degradation in $\mathrm{NaCl}$ conducted with $\mathrm{Ti}$ and $\mathrm{Fe}_{2} \mathrm{P}$-iron phosphate electrodes. Figure S9: Degradation efficiency of RhB. Text S4: Kinetic models. Table S1: Pseudo-first-order and pseudo-second-order rate constants and correlation coefficients of $\mathrm{RhB}$ dye on $\mathrm{Fe}_{2} \mathrm{P}$-iron phosphate film. Text S5: Fluorescence spectra of $\mathrm{Fe}_{2} \mathrm{P}$-iron phosphate catalyst in $20 \mu \mathrm{M}$ coumarin. Figure S10: Fluorescence spectra of $\mathrm{Fe}_{2} \mathrm{P}$ 
catalyst in $20 \mu \mathrm{M}$ coumarin before and after the test. Figure S11: Detection of HClO by DPD method. Figure S12: MS measurement of $\mathrm{H}_{2}$ and $\mathrm{O}_{2}$ gas during the RhB degradation. Text S6: Degradation mechanism of RhB dye. Text S7: Calculation of the current generation efficiency of HClO. Figure S13: LSV plots and SEM images of $\mathrm{Fe}_{2} \mathrm{P}$-iron phosphate electrode recorded before and after the recycling test. Figure S14: HPLC of $1 \times 10^{-5} \mathrm{M}$ RhB solution in the presence of $\mathrm{NaCl}, \mathrm{NH}_{4} \mathrm{Cl}$ and $\mathrm{Na}_{2} \mathrm{SO}_{4}$. Text S8: Phytotoxicity test using Lepidium sativum L. Figure S15: Images of Lepidium sativum L. incubated in Petri dishes with RhB before and after EC treatment. Figure S16: LSV of $\mathrm{Fe}_{2} \mathrm{P}$-iron phosphate catalyst in $\mathrm{NaCl}$ seeded with $1.1 \times 10^{8} \mathrm{CFU} / \mathrm{mL}$ of $E$. coli bacteria and $I-t$ plot obtained in $0.06 \mathrm{M} \mathrm{NaCl}+1.1 \times 10^{8} \mathrm{CFU} / \mathrm{mL}$ of $E$. coli at $2.0 \mathrm{~V}$ vs. RHE. Table S2: Selected materials used in EC degradation of different dye molecules. Table S3: Selected materials used in EC inactivation of E.coli bacteria. Text S9: Synthesis and characterization of $\mathrm{Fe}_{2} \mathrm{P}$ thin film. Text S10: Catalyst evaluation. Figure S17: Photograph of the cappuccino cell and EC cell used in the dye degradation studies. Table S4: Characteristics of RhB dye. [67-92] are cited in the Supplementary Materials.

Author Contributions: T.C. designed and conducted the experiments, analyzed the data and wrote the manuscript. M.M. contributed to DPD measurements. J.T. carried out the HPLC measurements. L.B. contributed to phytotoxicity tests, inactivation of $E$. coli bacteria and fundraising. P.S. carried out the XPS measurements. E.J. contributed to phytotoxicity tests. J.S.S. contributed to manuscript editing. M.V. contributed to manuscript editing. A.F. contributed to manuscript editing. S.E. supervised the work and contributed to data analysis, manuscript writing, editing, fundraising and project administration. All authors have read and agreed to the published version of the manuscript.

Funding: This research was funded by the Slovenian Research Agency under the bilateral project for scientific cooperation between Slovenia and the State of Israel (NI-0002). Scholarships were provided by the Public Scholarship, Development, Disability and Maintenance Fund of Slovenia for PhD studies at the University of Nova Gorica. Financial support was provided by the Slovenian Research Agency (research core funding: P2-0412).

Data Availability Statement: Data are contained within the article or Supplementary Materials.

Acknowledgments: This work was financially supported by the Slovenian Research Agency under the bilateral project for scientific cooperation between Slovenia and the State of Israel (NI-0002). T. Chouki and M. Machreki acknowledge the scholarships provided by the Public Scholarship, Development, Disability and Maintenance Fund of Slovenia (Ad futura program) for PhD studies at the University of Nova Gorica. S. Emin and M. Valant acknowledge the financial support from the Slovenian Research Agency (research core funding: P2-0412).

Conflicts of Interest: The authors declare that they have no known competing financial interests or personal relationships that could have influenced the work reported in this paper.

\section{References}

1. Oturan, M.A. Electrochemical advanced oxidation technologies for removal of organic pollutants from water. Environ. Sci. Pollut. Res. 2014, 21, 8333-8335. [CrossRef] [PubMed]

2. Faouzi Elahmadi, M.; Bensalah, N.; Gadri, A. Treatment of aqueous wastes contaminated with Congo Red dye by electrochemical oxidation and ozonation processes. J. Hazard. Mater. 2009, 168, 1163-1169. [CrossRef] [PubMed]

3. Anas, M.; Han, D.S.; Mahmoud, K.; Park, H.; Abdel-Wahab, A. Photocatalytic degradation of organic dye using titanium dioxide modified with metal and non-metal deposition. Mater. Sci. Semicond. Process. 2015, 41, 209-218. [CrossRef]

4. Raza, N.; Raza, W.; Gul, H.; Kim, K.H. ZnO-ZnTe hierarchical superstructures as solar-light-activated photocatalysts for azo dye removal. Environ. Res. 2021, 194, 110499. [CrossRef] [PubMed]

5. Fan, L.; Zhou, Y.; Yang, W.; Chen, G.; Yang, F. Electrochemical degradation of aqueous solution of Amaranth azo dye on ACF under potentiostatic model. Dye. Pigment. 2008, 76, 440-446. [CrossRef]

6. Zhao, S.; Li, S.; Zhao, Z.; Su, Y.; Long, Y.; Zheng, Z.; Cui, D.; Liu, Y.; Wang, C.; Zhang, X.; et al. Microwave-assisted hydrothermal assembly of 2D copper-porphyrin metal-organic frameworks for the removal of dyes and antibiotics from water. Environ. Sci. Pollut. Res. 2020, 27, 39186-39197. [CrossRef]

7. Hashim, K.S.; Kot, P.; Zubaidi, S.L.; Alwash, R.; Al Khaddar, R.; Shaw, A.; Al-Jumeily, D.; Aljefery, M.H. Energy efficient electrocoagulation using baffle-plates electrodes for efficient Escherichia coli removal from wastewater. J. Water Process Eng. 2020, 33, 101079. [CrossRef]

8. Bensalah, N.; Louhichi, B.; Abdel-Wahab, A. Electrochemical oxidation of succinic acid in aqueous solutions using boron doped diamond anodes. Int. J. Environ. Sci. Technol. 2012, 9, 135-143. [CrossRef] 
9. Ammar, H.B.; Brahim, M.B.; Abdelhédi, R.; Samet, Y. Green electrochemical process for metronidazole degradation at BDD anode in aqueous solutions via direct and indirect oxidation. Sep. Purif. Technol. 2016, 157, 9-16. [CrossRef]

10. Patil, S.A.; Hägerhäll, C.; Gorton, L. Electron transfer mechanisms between microorganisms and electrodes in bioelectrochemical systems. Bioanal. Rev. 2014, 1, 71-129. [CrossRef]

11. Koo, M.S.; Chen, X.; Cho, K.; An, T.; Choi, W.; Chen, X.; Cho, K.; An, T.; Choi, W. In situ photoelectrochemical chloride activation using a $\mathrm{WO}_{3}$ electrode for oxidative treatment with simultaneous $\mathrm{H}_{2}$ evolution under visible light. Environ. Sci. Technol. 2019, 53, 9926-9936. [CrossRef] [PubMed]

12. Moreira, F.C.; Boaventura, R.A.R.; Brillas, E.; Vilar, V.J.P. Electrochemical advanced oxidation processes: A review on their application to synthetic and real wastewaters. Appl. Catal. B Environ. 2017, 202, 217-261. [CrossRef]

13. Wacławek, S.; Lutze, H.V.; Grübel, K.; Padil, V.V.T.; Černík, M.; Dionysiou, D.D. Chemistry of persulfates in water and wastewater treatment: A review. Chem. Eng. J. 2017, 330, 44-62. [CrossRef]

14. Lemeyonouin, P.; Guillaume, A.; Honoré, K.K.; Albert, T. Influence of chlorides on the electrochemical oxidation of formic acid on thermally prepared platinum electrodes. Int. J. Pure Appl. Sci. Technol. 2013, 14, 33-43.

15. Baddouh, A.; Bessegato, G.G.; Rguiti, M.M.; El Ibrahimi, B.; Bazzi, L.; Hilali, M.; Zanoni, M.V.B. Electrochemical decolorization of Rhodamine B dye: Influence of anode material, chloride concentration and current density. J. Environ. Chem. Eng. 2018, 6 , 2041-2047. [CrossRef]

16. Babu, B.R.; Venkatesan, P.; Kanimozhi, R.; Basha, C.A. Removal of pharmaceuticals from wastewater by electrochemical oxidation using cylindrical flow reactor and optimization of treatment conditions. J. Environ. Sci. Health-Part A Toxic/Hazard. Subst. Environ. Eng. 2009, 44, 985-994. [CrossRef]

17. Martínez-Huitle, C.A.; Ferro, S. Electrochemical oxidation of organic pollutants for the wastewater treatment: Direct and indirect processes. Chem. Soc. Rev. 2006, 35, 1324-1340. [CrossRef]

18. Ganizadeh, F.; Rezaee, A.; Godini, H. Elimination of pathogenic bacteria using electrochemical process containing steel mesh electrode. J. Adv. Environ. Health Res. 2017, 5, 23-28. [CrossRef]

19. Yang, Y. Recent advances in the electrochemical oxidation water treatment: Spotlight on byproduct control. Front. Environ. Sci. Eng. 2020, 14, 1264-1267. [CrossRef]

20. Duan, T.; Chen, Y.; Wen, Q.; Duan, Y. Novel composition graded Ti/Ru-Sb-SnO 2 electrode synthesized by selective electrodeposition and its application for electrocatalytic decolorization of dyes. J. Phys. Chem. C 2015, 119, 7780-7790. [CrossRef]

21. Maharana, D.; Niu, J.; Gao, D.; Xu, Z.; Shi, J. Electrochemical degradation of Rhodamine B over Ti/SnO $2-S b$ electrode. Water Environ. Res. 2015, 87, 304-311. [CrossRef] [PubMed]

22. Bergmann, M.E.H.; Koparal, A.S. Studies on electrochemical disinfectant production using anodes containing RuO 2 . J. Appl. Electrochem. 2005, 35, 1321-1329. [CrossRef]

23. Martínez-Huitle, C.A.; Brillas, E. Electrochemical alternatives for drinking water disinfection. Angew. Chem.-Int. Ed. 2008, 47, 1998-2005. [CrossRef] [PubMed]

24. Bensalah, N.; Abdel-Wahab, A. Electrochemical inactivation of P. Aeruginosa, A. hydrophila, L. pneumophila using boron doped diamond anodes. J. Adv. Oxid. Technol. 2013, 16, 9-15. [CrossRef]

25. Barashkov, N.N.; Eisenberg, D.; Eisenberg, S.; Shegebaeva, G.S.; Irgibaeva, I.S.; Barashkova, I.I. Electrochemical chlorine-free AC disinfection of water contaminated with Salmonella typhimurium bacteria. Russ. J. Electrochem. 2010, 46, 306-311. [CrossRef]

26. Jeong, J.; Kim, J.Y.; Cho, M.; Choi, W.; Yoon, J. Inactivation of Escherichia coli in the electrochemical disinfection process using a Pt anode. Chemosphere 2007, 67, 652-659. [CrossRef]

27. Ghasemian, S.; Asadishad, B.; Omanovic, S.; Tufenkji, N. Electrochemical disinfection of bacteria-laden water using antimonydoped tin-tungsten-oxide electrodes. Water Res. 2017, 126, 299-307. [CrossRef]

28. Ajiboye, T.O.; Babalola, S.O.; Onwudiwe, D.C. Photocatalytic inactivation as a method of elimination of E. coli from drinking water. Appl. Sci. 2021, 11, 1313. [CrossRef]

29. Jain, R.; Sharma, N.; Bhargava, M. Electrochemical degradation of Rhodamine B dye in textile and paper industries effluent. J. Sci. Ind. Res. 2003, 62, 1138-1144.

30. Kothari, M.S.; Shah, K.A. Electrochemical oxidation for decolorization of Rhodamine-B dye using mixed metal oxide electrode: Modeling and optimization. Water Sci. Technol. 2020, 81, 720-731. [CrossRef]

31. Ahmadi, A.; Wu, T. Inactivation of E. coli using a novel $\mathrm{TiO}_{2}$ nanotube electrode. Environ. Sci. Water Res. Technol. 2017, 3, 534-545. [CrossRef]

32. Yang, M.; Liu, X.; Chen, J.; Meng, F.; Zhang, Y.; Brandl, H.; Lippert, T.; Chen, N. Photocatalytic and electrochemical degradation of methylene blue by titanium dioxide. Chin. Sci. Bull. 2014, 59, 1964-1967. [CrossRef]

33. Li, $\mathrm{H}$.; Zhu, X.; Ni, J. Inactivation of Escherichia coli in $\mathrm{Na}_{2} \mathrm{SO}_{4}$ electrolyte using boron-doped diamond anode. Electrochim. Acta 2010, 56, 448-453. [CrossRef]

34. Li, X.Y.; Diao, H.F.; Fan, F.X.J.; Gu, J.D.; Ding, F.; Tong, A.S.F. Electrochemical wastewater disinfection: Identification of its principal germicidal actions. J. Environ. Eng. 2004, 130, 1217-1221. [CrossRef]

35. Vos, J.G.; Koper, M.T.M. Measurement of competition between oxygen evolution and chlorine evolution using rotating ring-disk electrode voltammetry. J. Electroanal. Chem. 2018, 819, 260-268. [CrossRef]

36. Wang, L.; Qin, M.; Yang, W.; Gao, Y.; Li, Y.Y. Efficient electrochemical water oxidation and oxidative degradation of Rhodamine B: A comparative study using high-purity birnessites containing $\mathrm{Li}^{+}, \mathrm{Na}^{+}$or $\mathrm{K}^{+}$ions. ChemistrySelect 2017, 2, 5587-5594. [CrossRef] 
37. Chouki, T.; Lazarević, D.; Donkova, B.V.; Emin, S. Synthesis of efficient iron phosphide catalyst for electrocatalytic hydrogen generation. Bulg. Chem. Commun. 2021, 53, 72-77. [CrossRef]

38. Yao, Y.; Mahmood, N.; Pan, L.; Shen, G.; Zhang, R.; Gao, R.; Aleem, F.E.; Yuan, X.; Zhang, X.; Zou, J.J. Iron phosphide encapsulated in P-doped graphitic carbon as efficient and stable electrocatalyst for hydrogen and oxygen evolution reactions. Nanoscale 2018, 10, 21327-21334. [CrossRef]

39. Guo, R.; Lai, X.; Huang, J.; Du, X.; Yan, Y.; Sun, Y.; Zou, G.; Xiong, J. Phosphate-based electrocatalysts for water splitting: Recent Progress. ChemElectroChem 2018, 5, 3822-3834. [CrossRef]

40. Tang, K.; Wang, X.; Wang, M.; Xie, Y.; Zhou, J.; Yan, C. Highly sensitive activity on Ni/Fe ratio of monodispersed ternary nickel iron phosphide for efficient water oxidation. ChemElectroChem 2017, 4, 2150-2157. [CrossRef]

41. Lei, Z.; Bai, J.; Li, Y.; Wang, Z.; Zhao, C. Fabrication of nanoporous nickel-iron hydroxylphosphate composite as bifunctional and reversible catalyst for highly efficient intermittent water splitting. ACS Appl. Mater. Interfaces 2017, 9, 35837-35846. [CrossRef]

42. Li, P.; Wang, S.; Samo, I.A.; Zhang, X.; Wang, Z.; Wang, C.; Li, Y.; Du, Y.; Zhong, Y.; Cheng, C.; et al. Common-ion effect triggered highly sustained seawater electrolysis with additional $\mathrm{NaCl}$ production. Research 2020, 2020, 2872141. [CrossRef] [PubMed]

43. Li, P.; Zeng, H.C. Promoting electrocatalytic oxygen evolution over transition-metal phosphide-based nanocomposites via architectural and electronic engineering. ACS Appl. Mater. Interfaces 2019, 11, 46825-46838. [CrossRef] [PubMed]

44. Li, P.; Zeng, H.C. Bimetallic Ni-Fe phosphide nanocomposites with a controlled architecture and composition enabling highly efficient electrochemical water oxidation. J. Mater. Chem. A 2018, 6, 2231-2238. [CrossRef]

45. Chouki, T.; Machreki, M.; Emin, S. Solvothermal synthesis of iron phosphides and their application for efficient electrocatalytic hydrogen evolution. Int. J. Hydrogen Energy 2020, 45, 21473-21482. [CrossRef]

46. Park, J.; Koo, B.; Hwang, Y.; Bae, C.; An, K.; Park, J.G.; Park, H.M.; Hyeon, T. Novel synthesis of magnetic Fe 2 P nanorods from thermal decomposition of continuously delivered precursors using a syringe pump. Angew. Chem.-Int. Ed. 2004, 43, 2282-2285 [CrossRef] [PubMed]

47. Rasras, A.; Hamdi, R.; Mansour, S.; Samara, A.; Haik, Y. Study of the magnetocaloric effect in single-phase antiferromagnetic $\mathrm{GdMnO}_{3}$. J. Phys. Chem. Solids 2021, 149, 109798. [CrossRef]

48. Sharif, F.; Roberts, E.P.L. Electrochemical oxidation of an organic dye adsorbed on tin oxide and antimony doped tin oxide graphene composites. Catalysts 2020, 10, 263. [CrossRef]

49. Lu, C.; Jothi, P.R.; Thersleff, T.; Budnyak, T.M.; Rokicinska, A.; Yubuta, K.; Dronskowski, R.; Kuśtrowski, P.; Fokwa, B.P.T.; Slabon, A. Nanostructured core-shell metal borides-oxides as highly efficient electrocatalysts for photoelectrochemical water oxidation. Nanoscale 2020, 12, 3121-3128. [CrossRef]

50. Chouki, T.; Donkova, B.; Aktarla, B.; Stefanov, P.; Emin, S. Growth of MoSe 2 electrocatalyst from metallic molybdenum nanoparticles for efficient hydrogen evolution. Mater. Today Commun. 2021, 26, 101976. [CrossRef]

51. Li, P.; Li, W.; Chen, R.; Lin, Y. Boosting the oxygen evolution electrocatalysis performance of iron phosphide via architectural design and electronic modulation. ACS Sustain. Chem. Eng. 2020, 8, 9206-9216. [CrossRef]

52. Gendel, Y.; Lahav, O. Revealing the mechanism of indirect ammonia electrooxidation. Electrochim. Acta 2012, 63, 209-219. [CrossRef]

53. Wang, H.; Zhang, X.; Su, Y.; Yu, H.; Chen, S.; Quan, X.; Yang, F. Photoelectrocatalytic oxidation of aqueous ammonia using TiO 2 nanotube arrays. Appl. Surf. Sci. 2014, 311, 851-857. [CrossRef]

54. Baddouh, A.; El Ibrahimi, B.; Amaterz, E.; Rguiti, M.M.; Bazzi, L.; Hilali, M. Removal of the Rhodamine B dye at Ti/ $\mathrm{Ru}_{0.3} \mathrm{Ti}_{0.7} \mathrm{O}_{2}$ anode using flow cell system. J. Chem. 2019, 2019, 1424797. [CrossRef]

55. Zhang, Y.; Ji, Y.; Li, J.; Bai, J.; Chen, S.; Li, L.; Wang, J.; Zhou, T.; Jiang, P.; Guan, X.; et al. Efficient ammonia removal and toxic chlorate control by using $\mathrm{BiVO}_{4} / \mathrm{WO}_{3}$ heterojunction photoanode in a self-driven PEC-chlorine system. J. Hazard. Mater. 2021, 402, 123725. [CrossRef] [PubMed]

56. Xiang, Q.; Yu, J.; Wong, P.K. Quantitative characterization of hydroxyl radicals produced by various photocatalysts. J. Colloid Interface Sci. 2011, 357, 163-167. [CrossRef] [PubMed]

57. Bru, R.; Van Duijne, A.K.; Braakhuis, L.; Saha, P.; Jeremiasse, A.W.; Mei, B.; Mul, G. Comparative analysis of photocatalytic and electrochemical degradation of 4-Ethylphenol in saline conditions. Environ. Sci. Technol. 2019, 53, 8725-8735. [CrossRef]

58. Ji, Y.; Bai, J.; Li, J.; Luo, T.; Qiao, L.; Zeng, Q.; Zhou, B. Highly selective transformation of ammonia nitrogen to $\mathrm{N}_{2}$ based on a novel solar-driven photoelectrocatalytic-chlorine radical reactions system. Water Res. 2017, 125, 512-519. [CrossRef]

59. Iguchi, S.; Miseki, Y.; Sayama, K. Efficient hypochlorous acid ( $\mathrm{HClO})$ production: Via photoelectrochemical solar energy conversion using a $\mathrm{BiVO}_{4}$-based photoanode. Sustain. Energy Fuels 2018, 2, 155-162. [CrossRef]

60. Benvenuti, T.; Gabriel, A.P.; Heberle, A.N.A.; Lucena, M.P.P.; Petter, P.M.H.; Meneguzzi, Á.; Bernardes, A.M. Evaluation of direct photolysis, electrooxidation and photoelectrooxidation for Rhodamine-B degradation. Braz. J. Chem. Eng. 2018, 35, 957-968. [CrossRef]

61. Norouzi, N.; Choudhury, F.A.; El-Kaderi, H.M. Iron phosphide doped, porous carbon as an efficient electrocatalyst for oxygen reduction reaction. ACS Appl. Energy Mater. 2020, 3, 2537-2546. [CrossRef]

62. Zhang, Y.; Wang, Y.; Luo, R.; Yang, Y.; Lu, Y.; Guo, Y.; Liu, X.; Cao, S.; Kim, J.K.; Luo, Y. A 3D porous FeP/rGO modulated separator as a dual-function polysulfide barrier for high-performance lithium sulfur batteries. Nanoscale Horiz. 2020, 5, 530-540. [CrossRef] [PubMed] 
63. Yuan, R.; Ramjaun, S.N.; Wang, Z.; Liu, J. Effects of chloride ion on degradation of Acid Orange 7 by sulfate radical-based advanced oxidation process: Implications for formation of chlorinated aromatic compounds. J. Hazard. Mater. 2011, 196, 173-179. [CrossRef]

64. Radjenovic, J.; Sedlak, D.L. Challenges and opportunities for electrochemical processes as next-generation technologies for the treatment of contaminated water. Environ. Sci. Technol. 2015, 49, 11292-11302. [CrossRef] [PubMed]

65. de Araújo, D.M.; Sáez, C.; Martínez-Huitle, C.A.; Cañizares, P.; Rodrigo, M.A. Influence of mediated processes on the removal of Rhodamine with conductive-diamond electrochemical oxidation. Appl. Catal. B Environ. 2015, 166-167, 454-459. [CrossRef]

66. Machreki, M.; Chouki, T.; Martelanc, M.; Butinar, L.; Vodopivec, B.M.; Emin, S. Preparation of porous $\alpha-\mathrm{Fe}_{2} \mathrm{O}_{3}$ thin films for efficient photoelectrocatalytic degradation of Basic blue 41 dye. J. Environ. Chem. Eng. 2021, 9, 105495. [CrossRef]

67. Zhou, X.; Liu, D.; Bu, H.; Deng, L.; Liu, H.; Yuan, P.; Du, P.; Song, H. XRD-based quantitative analysis of clay minerals using reference intensity ratios, mineral intensity factors, Rietveld, and full pattern summation methods: A critical review. Solid Earth Sci. 2018, 3, 16-29. [CrossRef]

68. Von Dreele, R.B. Protein crystal structure analysis from high-resolution X-Ray powder-diffraction data. Methods Enzymol. 2003, 368, 254-267. [CrossRef] [PubMed]

69. Nath, D.; Singh, F.; Das, R. X-ray diffraction analysis by Williamson-Hall, Halder-Wagner and size-strain plot methods of CdSe nanoparticles- a comparative study. Mater. Chem. Phys. 2020, 239, 122021. [CrossRef]

70. Zhu, K.; Ren, X.; Sun, X.; Zhu, L.; Sun, Z. Effect of supporting electrolyte on the surface corrosion and anodic oxidation performance of graphite electrode. Electrocatalysis 2019, 10, 549-559. [CrossRef]

71. Society, T.E. Water electrolysis using diamond thin film electrodes. J. Electrochem. Soc. 1998, 145, 2358.

72. Kuo, D.Y.; Paik, H.; Nelson, J.N.; Shen, K.M.; Schlom, D.G.; Suntivich, J. Chlorine evolution reaction electrocatalysis on RuO $2(110)$ and $\mathrm{IrO}_{2}$ (110) grown using molecular-beam epitaxy. J. Chem. Phys. 2019, 150, 041726. [CrossRef] [PubMed]

73. McCrory, C.C.L.; Jung, S.; Peters, J.C.; Jaramillo, T.F. Benchmarking heterogeneous electrocatalysts for the oxygen evolution reaction. J. Am. Chem. Soc. 2013, 135, 16977-16987. [CrossRef] [PubMed]

74. Sivarajasekar, N.; Srileka, S.; Samson Arun Prasath, S.; Robinson, S.; Saravanan, K. Kinetic modeling for biosorption of Metylene Blue onto $\mathrm{H}_{3} \mathrm{PO}_{4}$ activated acacia arabica. Carbon Lett. 2008, 9, 181-187. [CrossRef]

75. Mehta, A.; Mishra, A.; Kainth, S.; Basu, S. Carbon quantum dots/ $\mathrm{TiO}_{2}$ nanocomposite for sensing of toxic metals and photodetoxification of dyes with kill waste by waste concept. Mater. Des. 2018, 155, 485-493. [CrossRef]

76. Oliveira, F.H.; Osugi, M.E.; Paschoal, F.M.M.; Profeti, D.; Olivi, P.; Zanoni, M.V.B. Electrochemical oxidation of an acid dye by active chlorine generated using Ti/Sn(1-x $) \mathrm{Ir}_{\mathrm{x}} \mathrm{O}_{2}$ electrodes. J. Appl. Electrochem. 2007, 37, 583-592. [CrossRef]

77. Cho, K.; Hoffmann, M.R. Urea degradation by electrochemically generated reactive chlorine species: Products and reaction pathways. Environ. Sci. Technol. 2014, 48, 11504-11511. [CrossRef] [PubMed]

78. Kusmierek, E. Semiconductor electrode materials applied in photoelectrocatalytic wastewater treatment-An overview. Catalysts 2020, 10, 439. [CrossRef]

79. Mañas, P.; De las Heras, J. Phytotoxicity test applied to sewage sludge using Lactuca sativa L. and Lepidium sativum L. seeds. Int. J. Environ. Sci. Technol. 2018, 15, 273-280. [CrossRef]

80. Andrade, L.S.; Ruotolo, L.A.M.; Rocha-Filho, R.C.; Bocchi, N.; Biaggio, S.R.; Iniesta, J.; García-Garcia, V.; Montiel, V. On the performance of $\mathrm{Fe}$ and $\mathrm{Fe}, \mathrm{F}$ doped $\mathrm{Ti}-\mathrm{Pt} / \mathrm{PbO}_{2}$ electrodes in the electrooxidation of the Blue Reactive 19 dye in simulated textile wastewater. Chemosphere 2007, 66, 2035-2043. [CrossRef]

81. Chen, X.; Chen, G.; Gao, F.; Yue, P.L. High-performance Ti/BDD electrodes for pollutant oxidation. Environ. Sci. Technol. 2003, 37, 5021-5026. [CrossRef]

82. Fan, L.; Zhou, Y.; Yang, W.; Chen, G.; Yang, F. Electrochemical degradation of Amaranth aqueous solution on ACF. J. Hazard. Mater. 2006, 137, 1182-1188. [CrossRef] [PubMed]

83. Cameselle, C.; Pazos, M.; Sanromán, M.A. Selection of an electrolyte to enhance the electrochemical decolourisation of indigo. Optimisation and scale-up. Chemosphere 2005, 60, 1080-1086. [CrossRef] [PubMed]

84. Lopes, A.; Martins, S.; Morão, A.; Magrinho, M.; Gonçalves, I. Degradation of a textile dye C. I. Direct Red 80 by electrochemical processes. Port. Electrochim. Acta 2004, 22, 279-294. [CrossRef]

85. Salazar, R.; Ureta-Zañartu, M.S.; González-Vargas, C.; Brito, C.d.N.; Martinez-Huitle, C.A. Electrochemical degradation of industrial textile dye disperse yellow 3: Role of electrocatalytic material and experimental conditions on the catalytic production of oxidants and oxidation pathway. Chemosphere 2018, 198, 21-29. [CrossRef] [PubMed]

86. Chen, X.; Gao, F.; Chen, G. Comparison of Ti/BDD and Ti/ $\mathrm{SnO}_{2}-\mathrm{Sb}_{2} \mathrm{O}_{5}$ electrodes for pollutant oxidation. J. Appl. Electrochem. 2005, 35, 185-191. [CrossRef]

87. Chang, J.H.; Wang, Y.L.; Dong, C.D.; Shen, S.Y. Electrocatalytic degradation of azo dye by vanadium-doped $\mathrm{TiO}_{2}$ nanocatalyst. Catalysts 2020, 10, 482. [CrossRef]

88. Ozturk, D.; Yilmaz, A.E. Investigation of electrochemical degradation of Basic Red 13 dye in aqueous solutions based on COD removal: Numerical optimization approach. Int. J. Environ. Sci. Technol. 2020, 17, 3099-3110. [CrossRef]

89. Hamad, H.; Bassyouni, D.; El-Ashtoukhy, E.S.; Amin, N.; Abd El-Latif, M. Electrocatalytic degradation and minimization of specific energy consumption of synthetic azo dye from wastewater by anodic oxidation process with an emphasis on enhancing economic efficiency and reaction mechanism. Ecotoxicol. Environ. Saf. 2018, 148, 501-512. [CrossRef] [PubMed] 
90. Teng, X.; Li, J.; Wang, Z.; Wei, Z.; Chen, C.; Du, K.; Zhao, C.; Yang, G.; Li, Y. Performance and mechanism of methylene blue degradation by an electrochemical process. RSC Adv. 2020, 10, 24712-24720. [CrossRef]

91. Jeong, J.; Kim, J.Y.; Yoon, J. The role of reactive oxygen species in the electrochemical inactivation of microorganisms. Environ. Sci. Technol. 2006, 40, 6117-6122. [CrossRef] [PubMed]

92. Gusmão, I.C.C.P.; Moraes, P.B.; Bidoia, E.D. Studies on the electrochemical disinfection of water containing Escherichia coli using a dimensionally stable anode. Brazilian Arch. Biol. Technol. 2010, 53, 1235-1244. [CrossRef] 